\title{
Mechanisms of telomere maintenance and attrition: linking cancer and ageing
}

\author{
Jan G. Hengstler · Rosemarie Marchan • \\ Hermann M. Bolt
}

Published online: 24 April 2009

(C) Springer-Verlag 2009

In 1961 Hayflick and Moorhead had already demonstrated that normal diploid fibroblasts obtained from human fetal explants can be grown in culture for several months (Hayflick and Moorhead, 1961). However, it soon became clear that it was impossible to subcultivate these cells for more than approximately 50 times and as they later lost the ability to divide, a phenomenon named replicative senescence, whose molecular mechanism was elucidated only decades later. However, the basic observation required for understanding the link between senescence and cancer was already made in the winter of 1951, when a 31-year-old patient, Henrietta Lacks, underwent a biopsy for a suspicious cervical mass (review Finkel et al. 2007). Routinely, the biopsy was sent to one particular pathology lab. Deviating from routine, a portion of the biopsy was instead diverted to two scientists, George and Martha Gey, who had spent almost 20 years unsuccessfully attempting to grow human cells indefinitely in culture. Unfortunately, the biopsy was confirmed to be cervical cancer and despite surgery and radiotherapy, Henrietta Lacks died 8 months later. On the day of her death Martha and George Gey announced that for the first time, it was possible to continuously grow human cells in culture. In memory of the unfortunate Henrietta Lacks, the new cell line was named "HeLa".

A critical difference between the initially mentioned 'normal' fibroblasts and HeLa cells is their quantity of telomerase. Most normal cells express only limited amounts of

J. G. Hengstler $(\bowtie) \cdot$ R. Marchan · H. M. Bolt

Leibniz-Institut für Arbeitsforschung an der TU Dortmund,

Leibniz Research Centre for Working Environment

and Human Factors (IfADo), Ardeystrasse 67,

44139 Dortmund, Germany

e-mail: hengstler@ifado.de telomerase that are not sufficient to protect from telomere loss (Finkel et al. 2007). When telomere length falls below critical values, replicative senescence is induced. In contrast to fibroblasts, HeLa cells, similar to more than $95 \%$ of the numerously later established human cancer cell lines, aberrantly activate telomerase leading to immortality (Kim et al. 1994). The final proof that overexpressed telomerase is responsible for immortal growth came from experiments where telomerase was reintroduced into several primary human cell lines and shown to be sufficient to overcome replicative senescence (Bodnar et al. 1998).

Meanwhile, it has become clear that the well-known tumor suppressors retinoblastoma (RB), P53 and P21 are key players in the induction of senescence. In addition to telomere shortening, overexpression of oncogenes may cause senescence (Trost et al. 2005; Spangenberg et al. 2006). Oncogene-induced senescence may be interpreted as a fail-safe mechanism that must be bypassed before tumor progression can take place (Hengstler et al. 2006). However, environmental factors such as cigarette smoking and further DNA damaging substances can also accelerate telomere attrition and senescence (Acosta and Gil 2009; Finkel et al. 2007), thereby linking Toxicology to telomere and ageing research. On the other hand, genetic instability and DNA breakage may lead to amplification and increased expression of telomerase, although the involved mechanisms are not yet fully understood (Yatabe et al. 2004; Verdun and Karlseder 2007). Genetic instability (Florl and Schulz 2008; Hengstler and Bolt 2007, 2008; Stoiber et al. 2008; Beyersmann and Hartwig 2008) and DNA damage induction (Bolt 2008; Periyakaruppan et al. 2007; Borza et al. 2008; Bolt and Hengstler 2008; Zhang et al. 2008; Wong et al. 2008; Glahn et al. 2008; Krishnamurthi et al. 2008; Ullmann et al. 2008; Wozniak et al. 2007; Schmid et al. 2007; Nishimura et al. 2008; Schug et al. 2008) are 
examples of cutting-edge topics reported in our journal. Therefore, the editors are delighted by the contribution of Dr. Li Phing Liew and Dr. Chris J. Norbury from Oxford University to the current issue of Archives of Toxicology on telomere maintenance (Liew and Norbury 2009, this issue). In addition to providing a comprehensive review about the mechanisms and relevance of telomere maintenance, the authors also focus on the question how the double-stranded ends of chromosomes can be distinguished from the potentially catastrophic DNA double-strand breaks, although the chemical composition of broken DNA within the chromosomes does not obviously differ from normal DNA at the end of the chromosomes.

\section{References}

Acosta JC, Gil J (2009) A role for CXCR2 in senescence, but what about in cancer? Cancer Res 69:2167-2170

Beyersmann D, Hartwig A (2008) Carcinogenic metal compounds: recent insight into molecular and cellular mechanisms. Arch Toxicol 82:493-512

Bodnar AG, Ouellette M, Frolkis M, Holt SE, Chiu CP, Morin GB, Harley CB, Shay JW, Lichtsteiner S, Wright WE (1998) Extension of life-span by introduction of telomerase into normal human cells. Science 279:349-352

Bolt HM (2008) International symposium on genotoxic and carcinogenic thresholds. Arch Toxicol 82:981-982

Bolt HM, Hengstler JG (2008) Aluminium and lead toxicity revisited: mechanisms explaining the particular sensitivity of the brain to oxidative damage. Arch Toxicol 82:787-788

Borza A, Plöttner S, Wolf A, Behm C, Selinski S, Hengstler JG, Roos PH, Bolt HM, Kuhlmann J, Föllmann W (2008) Synergism of aromatic amines and benzo[a]pyrene in induction of Ah receptordependent genes. Arch Toxicol 82:973-980

Finkel T, Serrano M, Blasco MA (2007) The common biology of cancer and ageing. Nature 448:767-774

Florl AR, Schulz WA (2008) Chromosomal instability in bladder cancer. Arch Toxicol 82:173-182

Glahn F, Schmidt-Heck W, Zellmer S, Guthke R, Wiese J, Golka K, Hergenröder R, Degen GH, Lehmann T, Hermes M, Schormann W, Brulport M, Bauer A, Bedawy E, Gebhardt R, Hengstler JG, Foth H (2008) Cadmium, cobalt and lead cause stress response, cell cycle deregulation and increased steroid as well as xenobiotic metabolism in primary normal human bronchial epithelial cells which is coordinated by at least nine transcription factors. Arch Toxicol 82:513-524

Hayflick L, Moorhead PS (1961) The serial cultivation of human diploid cell strains. Exp Cell Res 25:585-621

Hengstler JG, Bolt HM (2007) Induction and control of oxidative stress. Arch Toxicol 81:823-824

Hengstler JG, Bolt HM (2008) Loss of DNA damage checkpoint genes: switch from preferential induction of point mutations to chromosomal damage precedes the transition towards an aggressive cancer type. Arch Toxicol 82:341-342

Hengstler JG, Bockamp EO, Hermes M, Brulport M, Bauer A, Schormann W, Schiffer IB, Hausherr C, Eshkind L, Antunes C, Franzen A, Krishnamurthi K, Lausch E, Lessig R, Chakrabarti T, Prawitt D, Zabel B, Spangenberg C (2006) Oncogene-blocking therapies: new insights from conditional mouse tumor models. Curr Cancer Drug Targets 6:603-612
Kim NW, Piatyszek MA, Prowse KR, Harley CB, West MD, Ho PL, Coviello GM, Wright WE, Weinrich SL, Shay JW (1994) Specific association of human telomerase activity with immortal cells and cancer. Science 266:2011-2015

Krishnamurthi K, Saravana Devi S, Hengstler JG, Hermes M, Kumar K, Dutta D, Muhil Vannan S, Subin TS, Yadav RR, Chakrabarti $\mathrm{T}$ (2008) Genotoxicity of sludges, wastewater and effluents from three different industries. Arch Toxicol 82:965-971

Liew LP, Norbury CJ (2009) Telomere maintenance: all's well that ends well. Arch Toxicol (this issue)

Nishimura J, Dewa Y, Okamura T, Muguruma M, Jin M, Saegusa Y, Umemura T, Mitsumori K (2008) Possible involvement of oxidative stress in fenofibrate-induced hepatocarcinogenesis in rats. Arch Toxicol 82:641-654

Periyakaruppan A, Kumar F, Sarkar S, Sharma CS, Ramesh GT (2007) Uranium induces oxidative stress in lung epithelial cells. Arch Toxicol 81:389-395

Schmid K, Sassen A, Staudenmaier R, Kroemer S, Reichl FX, Harréus U, Hagen R, Kleinsasser N (2007) Mercuric dichloride induces DNA damage in human salivary gland tissue cells and lymphocytes. Arch Toxicol 81:759-767

Schug M, Heise T, Bauer A, Storm D, Blaszkewicz M, Bedawy E, Brulport M, Geppert B, Hermes M, Föllmann W, Rapp K, Maccoux L, Schormann W, Appel KE, Oberemm A, Gundert-Remy U, Hengstler JG (2008) Primary rat hepatocytes as in vitro system for gene expression studies: comparison of sandwich, Matrigel and 2D cultures. Arch Toxicol 82:923-931

Spangenberg C, Lausch EU, Trost TM, Prawitt D, May A, Keppler R, Fees SA, Reutzel D, Bell C, Schmitt S, Schiffer IB, Weber A, Brenner W, Hermes M, Sahin U, Türeci O, Koelbl H, Hengstler JG, Zabel BU (2006) ERBB2-mediated transcriptional up-regulation of the alpha5beta1 integrin fibronectin receptor promotes tumor cell survival under adverse conditions. Cancer Res 66:37153725

Stoiber T, Unger E, Dorn SB, Degen GH, Bolt HM (2008) Hydrophobic interaction of organic chemicals with microtubule assembly in vitro. Arch Toxicol 82:601-606

Trost TM, Lausch EU, Fees SA, Schmitt S, Enklaar T, Reutzel D, Brixel LR, Schmidtke $P$, Maringer M, Schiffer IB, Heimerdinger CK, Hengstler JG, Fritz G, Bockamp EO, Prawitt D, Zabel BU, Spangenberg C (2005) Premature senescence is a primary fail-safe mechanism of ERBB2-driven tumorigenesis in breast carcinoma cells. Cancer Res 65:840-849

Ullmann K, Müller C, Steinberg P (2008) Two essential modifications strongly improve the performance of the Fast Micromethod to identify DNA single- and double-strand breaks. Arch Toxicol 82:861-867

Verdun RE, Karlseder J (2007) Replication and protection of telomeres. Nature 447:924-931

Wong RH, Hu CW, Yeh CY, Chao MR, Chen CC, Huang JH, Chang SH, Lee SI, Lee HS (2008) Sulfotransferase 1A1 and glutathione $S$-transferase P1 genetic polymorphisms modulate the levels of urinary 8-hydroxy-2'-deoxyguanosine in betel quid chewers. Arch Toxicol 82:313-321

Wozniak K, Kolacinska A, Blasinska-Morawiec M, Morawiec-Bajda A, Morawiec Z, Zadrozny M, Blasiak J (2007) The DNA-damaging potential of tamoxifen in breast cancer and normal cells. Arch Toxicol 81:519-527

Yatabe N, Kyo S, Maida Y, Nishi H, Nakamura M, Kanaya T, Tanaka M, Isaka K, Ogawa S, Inoue M (2004) HIF-1-mediated activation of telomerase in cervical cancer cells. Oncogene 23:3708-3715

Zhang QH, Wu CF, Duan L, Yang JY (2008) Protective effects of ginsenoside $\operatorname{Rg}(3)$ against cyclophosphamide-induced DNA damage and cell apoptosis in mice. Arch Toxicol 82:117-123 